27 Waith, 'Staging', 186-7, observes that the booth 'must be large enough to contain at least the seven characters revealed there at the opening of Act IV, Scene iv'. Possibly, then, these characters remain within the booth as a source of ambient noise and eye-catching movement, rather than exiting immediately through the rear of the structure.

28 Herrup, The Common Peace, 193. The Oxford English Dictionary (OED) records that 'detect' has borne the specialized legal meaning of 'to inform against, accuse' since ca 1449 , with a cluster of occurrences around 1600.

29 See Luke Wilson, Theaters of Intention: Drama and the Law in Early Modern England (Stanford 2000), 131-4 for a summary of the wardship system and of theatrical responses to its perceived abuses by guardians like Justice Overdo.

30 Shapiro, A Culture of Fact, 8-9 notes that despite the assumed universality of human reason, in practice strict criteria including 'age, sex, education, social status ... reputation', and, of course, soundness of mind, governed authorities' choice of jurors.

31 One can imagine a number of potential visual frameworks for this scene. The tablets may be turned away from the audience, making Trouble-all's choice a tantalizing secret, while the visible choice of a suitor's name would significantly inflect spectators' impressions of the subsequent scramble for Grace's favour.

32 See Jackson Cope, 'Bartholomew Fair as Blasphemy', Renaissance Drama 8 (1965), 151-2; Richard Burt, Licensed by Authority: Ben Jonson and the Discourses of Censorship (Ithaca, 1993), 105-6, for examples.

33 Subha Mukherji has offered a similar assessment in 'Jonson's The New Inn and a Revisiting of the "Amorous Jurisdiction", Law and Literature 18.2 (2006), 154.

\title{
'The Hole in the Wall': Sacred Space and 'Third Space' in The Family of Love
}

The Family or House of Love, a mystical religious fellowship, was founded by Hendrick Niclaes, a Westphalian merchant, who settled in the northern German city of Emden around 1540; from there his perfectionist theology quickly spread across the Low Countries, France, and England. ${ }^{1}$ Between 1560 and 1580, and again in the years immediately after James I's accession to the throne, English Familism became visible through a series of pamphlets. $^{2}$ The play The Family of Love dates from around 1607, when it was entered into the Stationers' Register, and belongs to the second period of public debate about the Family in England. ${ }^{3}$ 
In the play Familists assemble at a seedy city inn, dubbed 'The Hole in the Wall', to worship under the leadership of Mistress Purge, wife of a London apothecary. Familism in the play is associated with withdrawal from civic sites and public affairs (Mistress Purge refuses to work in her husband's shop, for instance), while stage business centers on spatial contestation and incursion as two city libertines named Lipsalve and Gudgeon try to gain entrance to Family meetings at the Hole in the Wall for sexual pleasure, not spiritual illumination. Meanwhile, Mistress Purge's jealous husband secretly follows her to the inn to find out what she does behind its password-protected doors. Even what critics used to identify as the play's principal plot - the penniless Gerardine gaining entrance to the garret of Maria, niece to physician Dr Glister, who vehemently opposes the young man's suit - centers on questions of spatial invasion and conflict. Gerardine has himself furtively conveyed to Maria's chamber in a small trunk from which he rises as Jesus did from the tomb. His appearance, moreover, figures also as a parodic annunciation: 'Stay, sweet Maria! I bring thee ample joy / To check that sudden fear' (2.4.240-1). ${ }^{4}$ Parodying Catholicism's Marian cult, the scene underscores the confined girl's 'spotless innocence' (1.2.155) and stages Gerardine's spatial penetration which will lead to her pregnancy. In the play's final moments, Gerardine, disguised as man of law, publicly accuses Glister of impregnating his niece and then consents to marry Maria 'to redeem her lost good name' (5.3.2159). Publically he accepts a 'foster father' role, as Joseph did for the Virgin Mary (though Gerardine is of course the child's biological father).

Scholars who have written on the play usually emphasize Familism and the problem of transgressive speaking; a royal proclamation issued on October 3, 1580, claimed that Familists employed 'a monstrous new kind of speech'5 that threatened to undermine religious, social, and political order. Yet what defines Familism in the play, and becomes the dramatic focus, is its spatial ideology which links the play to larger questions about the spatial negotiation of religious dissent, and makes the stage an important site for resituating the sacred in early modern culture.

The Family of Love stages conflicting views of spatial sacrality. These views might best be defined in terms of expansive emplacement and civic accessibility, for one, and the rejection of a prevailing social order and its settled places of worship, for another. They approximate what theorist of ritual Jonathan Z. Smith has called a 'locative' map of the sacred, settled and dedicated to the establishment and maintenance of place, often by a clerical hierarchy; and a 'utopian' map, favouring mobility, dispersal, isolation, and 
marginalization. ${ }^{6}$ The play's staging of spatial conflict brought about by religious reformations gestures toward something like Smith's 'tentative third map', ${ }^{7}$ which plays the 'incongruities' of both maps against each other, in a kind of 'practical joke'8 that exposes the human labours that effect spatial sacralization without disavowing the need for this kind of labour. The stage thus functions also as a kind of 'third space' of the imagination, described by Henri Lefebvre. ${ }^{9}$ It offers possibilities for reconfiguring the relationship of oppositional types of sacred space by performing the spatial accommodation of religious toleration. Benjamin Kaplan claims that toleration was not only a concern for 'intellectuals and ruling elites, but for all people who lived in religiously mixed communities' and tried to effect the nonviolent accommodation of religious difference. ${ }^{10}$

The theatre was uniquely qualified to stage spatial processes of religious accommodation. Merging locative and utopian models of sacred space, The Family of Love generates a politics of early modern sacred space that consists not in the rancorous put-down of a group's spiritual and spatial deviation, but in an attempt at a limited form of social acceptance and incorporation. However, the play comically contests the Hole in the Wall's system of displacement and spatial marginalization because they are upheld by a woman. Opening the inn to public view through a trial scene in the physical setting of the theatre, the final tableau restructures the spiritual hierarchy of the Family rather than its spatial placement. The dramatic action not only underscores the political significance of situating the sacred in early modern England, but also argues for the toleration of utopian conceptions of sacred space while promoting a limited emplacement of the sacred on the periphery of 'public' space, in an emerging 'private' domain firmly under masculine control.

Conventional wisdom has it that religious reformers attempted to separate 'religion from place' and rejected traditional perceptions of sacred space. ${ }^{11}$ Niclaes, who claimed that being 'godded' meant the individual believer was a 'liuing Tabernacle or howse for [God's] Dwelling, and ... a Seate of his Christ', argued thus not unlike other reformers. ${ }^{12}$ Emphasizing the mobile bodies of believers and their small communal gatherings as the site of the sacred, reformers sought to connect with the spatial radicalism of the early Church. ${ }^{13}$ This subversive mobility and revolutionary dispersal of the sacred among the early followers of Jesus must be seen in relationship to the monumental public emplacement of the hegemonic locative faith that it resisted and challenged. 
The many early modern reformers who viewed sacred space in terms of early Christian utopianism undertook to develop a new spatial paradigm of sacred emplacement: the sacred city of the elect. Catharine Randall points out that 'Calvin's theology is inconceivable without the focal point of the city-space as theoretical and salvific model. Calvin's experimentations with the city-space of Geneva created a contemporary perception that Geneva was a holy city.' ${ }^{14}$ Geneva as a paradigm for spatial sacrality was part of a larger early modern impulse to remap spaces for the sacred in urban contexts. ${ }^{15}$ The fortified city, made up of godly homes and circumscribed by precise boundaries defining a re-imagined sacred space, became crucial to the spatial imagination of Huguenot architect Jacques Perret, whose plans for heavily secured cities and powerfully girded worship spaces were published two or three years after the Edict of Nantes. Johann Valentin Andreae's models for Christianopolis (1619) based on Perret's work similarly focused on the spatial separation and fortification of godly homes. ${ }^{16}$ These paradigms of sacred space remained largely in the realm of theory, however. Calvin's Geneva as a carefully bounded sacred city of the elect constituted one of the few exceptions, and, for a short time, so did the northern German city of Münster when, in 1534, a group of radical Anabaptists established a 'New Jerusalem' within its walls. ${ }^{17}$

Niclaes's writings also bear witness to this strain of urban utopianism. In Terra Pacis, one of his earliest works, he presents the reader with a spatial allegory about a pilgrimage through lands ravaged by intolerance and spiritual ignorance toward 'the holy Citee of Peace', where he shuts out the terror and violence of world in which Catholic and Protestant forces clash violently:

An immeasurably deep and mighty-strong river, and this tempestuous wynde, proceedeth-foorth out of a Water within this goodlie Citee: and they have always their Course of Streame and Rushing of Wynde, round-about the Citee, to the Destroying of all her Enemyes, because that the holy People of this Citee may dwell the more peaceable without Feares, and may remayne for evermore. ${ }^{18}$

Niclaes imagines the spiritual legitimacy of his city in environmental rather than architectural terms. It is within the topographic and atmospheric confines of an impassable river and powerful air currents that Niclaes situates his spiritual community to which only the believer who 'becometh as a Childe' (48) finds entrance. Unlike Calvin, who managed to restructure Geneva as a carefully circumscribed city of the Elect, Niclaes did not have a secure and 
powerful urban base from which to operate and was forced to conceive of his reformed fellowship as a mobile, utopian Huis der Liefde (House of Love). Its members might thus congregate anywhere, in 'underground' places of worship, on the margins of traditional communities and their sacred spaces.

Tracts against Familists made much of their spatial deviation, invariably expressed as a threatening move to the utopian margins which redefined sacred space. The royal proclamation from 1580 condemned the 'privy assemblies of divers simple unlearned people' who belonged to the Family. ${ }^{19}$ The ecclesiastical lawyer William Wilkinson wrote in a 1579 treatise that members of the sect met in houses 'far from company ... [that are] standing out of the common walke of people'. ${ }^{20}$ The lawyer John Rogers had argued a year earlier that Familists lectured 'in corners', and were 'called together ever in the night time: and commonly to such houses as be far from neighbors. ${ }^{21}$ Rogers claimed that the principal English Familist, Christopher Vittel, could be found 'trudging about the country', homeless and vagrant (D4v); and he connected Familism with the 'abhominations' of 'Munster' (A5r), concluding that 'in many thinges their doctrine in Munster and the Familie in England do agree' (B5r). It seems that out of necessity Familists might have drawn, to use the words of Benjamin Kaplan, 'a line around the family home', rendering it a sacred space in which to worship and marking a sharper distinction between 'communal and family spheres.' ${ }^{22}$ In a world in which the place of the sacred profoundly defined 'communal identity', ${ }^{23}$ especially through edifices in which a society worshiped, the open secret of containing religious dissent within a carefully circumscribed site left the fiction of spiritual and communal unity intact while allowing for nonconformist spiritual practices.

In the play, the stage generates a 'third map' that draws attention to the political stakes of situating the sacred by parodying the Family's Hole in the Wall as a kind of utopian house church in need of a 'counter-reformation'. The re-emplacement that becomes the play's dramatic subject centers on the gendering of spatial maneuvers. The play imagines spiritual and political coexistence through spatial accommodation in a restructured domestic sphere governed by men. If the play supports the dispersal and tenuous enclosure of the sacred at the margins - at first at the inn, the Family's unconventional 'home' - it does so by reintroducing a traditional gender hierarchy during the final scenes when it relocates sacred space from the inn to the family home, to a reformed domestic sphere. For much of the play, the sacred seems dispersed at the periphery, placed in an inappropriate spatial context by feminine spiritual authority. If we can read The Family of Love 
as a critical commentary on the social constitution of sacred space, a play whose spatial allegory provides an occasion for thought, then the result is the reestablishment of masculine control over the spatial diffusion and reformation of the sacred at the margins.

Reformations and counter-reformations profoundly challenged established models of sacred space. The play trades in fears of a utopian dispersal and relocation of the sacred, a mobile sacrality that threatened to give women access to religious authority. At stake in the play is not the dismantling of utopian or locative principles, but their remapping in a comic third space that makes the utopian rejection of traditional sacred space viable while emplacing the sacred in a newly sanctified and patriarchal domestic sphere. For much of the play, we witness an inversion and reorganization of traditional sacred space, as the Family meets under the leadership of a woman in the Hole in the Wall. Here members of the congregation 'crowd and thrust a man and a woman together' (3.2.958); the gendered spatial code, that, according to Margaret Aston, divided men from women inside public Christian churches from the third century CE onward, and that emplaced the sacred according to a strict gender logic has here collapsed. ${ }^{24}$ The placelessness of the sacred in the play suggests that even women can inhabit positions of religious authority.

The inn is the Family's 'house church', and as such flaunts spatial order in multiple registers. House churches in their domestic or 'private' emplacement could stand in utopian challenge to traditional, public sacred space. In the play the association of sacred space with the Hole in the Wall is radical, not only because of the obvious profanity of the site, but also because in this utopian site a woman is the presiding minister, or 'Elder' and boldly subverts physical and spiritual economies. Citing Georg Simmel, feminist geographer Daphne Spain observes that spatial segregation and concealment for the conveyance of 'mystical or religious knowledge' has traditionally reinforced masculine authority. In some cultures, 'men of a secret order [met in secret sites] and wore masks, [while] women were forbidden to approach them. If women discovered that the actors were their husbands, orders lost their 'whole significance' and became 'harmless mummeries'. ${ }^{25}$ In the play, spatial function and gender roles are inverted; the action moves toward the comic 'unmasking' of Mistress Purge and her Hole in the Wall and the reestablishment of masculine spatial authority in a theatrical third space, where Mistress Purge is exposed and ordered by Gerardine to return to her husband's 'land of Ham' (5.3.2137) — that is to the home and the marriage bed. 
Mistress Purge's subversion of the domestic spatial order, expressed through bodily deviation, brings the problem of Familist sacred space fully into focus. Her commitment to the Hole in the Wall as utopian sacred space means she challenges the spatial situation of the family home and wrests authority away from her husband. She does not 'keepe all at home' and occupy the space culturally assigned to her, as Henry Smith's 1591 treatise on marriage recommends; nor does she seek her 'pleasure ... within' the family home in a conventional fashion, by laboring for the economic good of the household. ${ }^{26}$ Her husband complains that she refuses to leave her room and tend to the family business:

'tis time for tradesmen to be in their shops, for he that tends well his shop, and hath an alluring wife with a graceful 'what d'ye lack' shall be sure to have good doings ... My wife, by ordinary course, should this morning have been at the Family, but now her soft pillow hath given her counsel to keep her bed. Master Doctor should minister to her: to whose pills she is so much accustomed, that now her body looks for them as duly as the moon shakes off the old and borrows new horns.

In her home, Mistress Purge redraws boundaries, remaining sequestered not just in her room, but in her bed, for the purposes of receiving the ambiguous 'ministrations' of Doctor Glister. The space of her bed, cut off from the bustle of the pharmacy below, becomes a site of enormous physical, economic, and spiritual transgression. Mistress Purge deliberately leaves behind the shop and the modicum of socio-economic power it offers. ${ }^{27} \mathrm{Her}$ refusal to adhere to the spatial order of her husband's shop and home - Purge's lines hint at his own cuckold's horns as well as the lunar and menstrual cycles regulated by the pills that may well perform the function of an emmenagogue - are in direct relation to Mistress Purge's radical re-ordering of space during the religious gatherings at the Hole in the Wall. There she enters into an alternative set of social relations that substitute the sensual and spiritual ministrations of the Family of Love for the structures and sites of marriage and kinship — the Hole in the Wall becomes the 'barren' substitute for the marital bed.

The female body is thus significant for conceptions of sacred space in the play. ${ }^{28}$ The comic 'ministrations' Dr. Glister performs on Mistress Purge's body complement the spiritual character of carefully bounded, marginal sacred space. Glister supplies Mistress Purge with prescriptions that, we may infer, assist her with contraception, so that the encounters in the Family 
of Love remain without physical consequences, which may also mean there will be no heir for Purge. Mistress Purge's practice of birth control stands in direct contrast to Maria's instant pregnancy, promoted by the secluded location of her chamber - and to the Virgin Mary's sacred fecundity as mater omnium, the mother of all. ${ }^{29}$ Reproductive success defines the viability of sacred space as Maria's fertility validates the sacrality of the 'fatal wall' (1.2.145) enclosing her garret. Gerardine moves into the position of patriarch when he opens up 'the chamber which confines [his] love' (1.2.105), ejects barren Mistress Purge from her bounded, marginal sacred space, and renders the family/Family home a newly consecrated site.

The drama of the threshold during which Mistress Purge presides over spatial initiation, underscores the Family's spatial deviancy in terms of reproductive subversion. Mistress Purge withdraws behind closed doors that open only to those who 'learn the word for [their] admittance' (3.2.983). At the inn, shrouded in darkness - 'with the candles out too; we fructify best i' the' dark' (3.2.929) — Mistress Purge engages, according to her husband, in 'some kind of private lecturing. Look to't, you that have such gadders to your wives' (3.2.1007-8). Withdrawal into the Hole in the Wall paradoxically makes Mistress Purge a 'gadder', a term associated by John Bale with Catholic 'mass-mongers, bead-babblers, saint-seekers, image-lighters, gadders to Compostella, Rome, Trier, and Thoulouse, with all their strange worshippings, not commanded of God' - with the topographic mobility of the sacred. ${ }^{30}$ Moving freely around town to a liminal site of worship, Mistress Purge's spatial deviancy also occasions a monstrous merging of old and new faiths. Moreover, the Hole in the Wall is a sanctuary where spiritual brothers and sisters join each other in bonds of affinity, established by equivocal and incorporeal glances of the eye, not by the physical bonds of kinship. To 'fructify' in the Family means to indulge in 'spiritual' bliss rather than in the biological production of offspring, according to Dryfat: 'Indeed I think we perform those functions best when we are not thrall to the fetters of the body' (3.2.932-3). The material limitations of sacred architecture and ritual practice that constrain traditional religious congregations, keeping their male and female parishioners in their proper places, do not apply to Familists in their murky sacred space.

But the dramatic iconography of the Hole in the Wall also lampoons a woman's pretensions to spiritual leadership and rejects the utopian anarchy that such a spatial arrangement generates. The 'Hole' is nothing like the 'natural sanctuaries', caves or subterranean sites, that in Mircea Eliade's reading 
are inherently sacred spaces and symbolize rebirth and regeneration. ${ }^{31}$ It might be argued that in terms of their architectural structure, Christian churches display a womb iconography, 32 which emphasizes the importance of the Doctrine of the Incarnation. ${ }^{33}$ But Mistress Purge's lectures on Familist sacred space point to the subversion of reproductive processes, to the short-circuiting of the womb's spiritual and social function:

MISTRESS PURGE we hold it not amiss to out the candles, for the soul sees best i' th' dark.

DRYfat You come to me now, Mistress Purge.

mistress purge Nay, I will come to you else, Master Dryfat. These senses, as you term them, are of much efficacy in carnal mixtures; that is, when we crowd and thrust a man and a woman together.

DRYfat I commend this zeal in you Mistress Purge; I desire much to be of your society.

(3.2.953-8, 963-4)

The neophyte, instructed by a female Elder, learns that the carefully circumscribed space of the Hole in the Wall means the utopian circulation of bodies, unencumbered by spatial restrictions that traditionally would keep women immobile. There is no segregating of men and women, no distinguishing between minister and flock; Familists belief in 'carnal mixtures', in a kind of unorthodox participatory ritual that throw men and women together in utter rejection of spatial customs. Conventional spatial negotiations within the precincts of public church buildings are not undertaken here, paradoxically, because locative spatial enclosure and seclusion makes utopian mobility possible. Familist sacred space allows for the heterodox circulation of bodies in a small, carefully bounded space, grotesquely directed (if such a term has much meaning for a group that throngs riotously) by a woman Elder.

Masculine masking (the mainstay of the early modern stage) makes the reform of spatial paradigms possible in the final scenes. Dressed up as a doctor of law, Gerardine challenges utopian notions of spatial sacredness in a public trial scene, during which the stage provides a 'third map' that brings together locative and utopian principles and reestablishes masculine authority over sacred space. Gerardine unmasks Familists' spiritual and spatial practices by bringing Mistress Purge back to a large, public site in the spectacular communal trial scene. When Gerardine hauls Mistress Purge out of the Family's privy den before the London populace, he gives her husband a chance to redress spatial imbalances caused by a feminized utopian faith. 
Master Purge tells of his clandestine spatial incursion at the Hole in the Wall and the bed-trick he played on his wife during which he obtained her wedding ring as proof of her spatial deviancy. The problems generated by a feminine religious culture of spatial subversion are resolved. Kristen Poole reads the trial scene as 'a mockery of legal and patriarchal privilege' that 'vindicates and sanctions' Mistress Purge's sexual promiscuity at the inn. ${ }^{34}$ But the spatial drama of this scene makes it clear that the comic third map of the stage reestablishes a patriarchal economy of sacred space where the role of 'religious specialist' (defined as one who may circumscribe space and render it sacred) is reassigned to a man. Mistress Purge's religious freedom has been severely curtailed and the utopian sacred space of the Hole in the Wall redefined, for the men - Gerardine, aided by Dryfat, Club, and Purge - 'wrest [its] smock law now in hand to [their] club law' (5.2.1824-5). The public space of the theatre becomes an agent and guarantor of a new geography of the sacred as Mistress Purge's sacred space is exposed and reformed.

In the final trial scene masking is vital to the counter-reformation of utopian sacred space. Joanne Altieri rightly considers Gerardine a 'trickster' figure. ${ }^{35}$ Indeed, Gerardine's disguise makes him a trickster who exposes spatial subversion without letting on what he himself has done in Maria's chamber. At the same time, his performance of the role of 'foster father' outwardly reestablishes spatial order while leaving room for utopian spatial nonconformity. Gerardine delivers a significant blow to Mistress Purge's spatial dissent: 'What starting-hole ha' you now, Mistress Purge?' (5.3.2018). She quickly tries to adjust her position: 'E'en the sanctuary of a safe conscience' (5.2.2020). Mistress Purge tries to withdraw into the 'sacred space' of her soul, claiming that she 'will do as the spirit shall enable me' (5.3.2151), but Gerardine's successful masked performance makes Mistress Purge's return to the 'Hole in the Wall' impossible. After dismantling the Family's illicit sanctuary and winning Maria's hand, Gerardine unmasks himself and then invites the men in the play to 'join with [him] / For approbation of our Family' (5.3.2172-3, emphasis added). The public stage's 'third map' reclaims utopian sacred space. Gerardine's words hint at the continuation of utopian spatial practices but also offers locative modifications: the Family's sacred space will be a bonafide 'house church', a domestic space where men are in charge and women are kept in the spaces that God and men have assigned to them. 


\section{Notes}

1 Jean Dietz Moss, “'Godded with God": Hendrick Niclaes and his Family of Love', Transactions of the American Philosophical Society 71 (1981); Alastair Hamilton, The Family of Love (Cambridge, 1981).

2 Christopher Marsh, The Family of Love in English Society, 1550-1630 (Cambridge, 1994).

3 On the play's attributions to Thomas Middleton, Lording Barry, and John Marston, see Gary Taylor, Paul Mulholland, and MacD. P. Jackson, 'Thomas Middleton, Lording Barry, and The Family of Love', Papers of the Bibliographical Society of America 93 (1999); Charles Cathcart, Marston, Rivalry, Rapprochement, and Jonson (Burlington, 2008). I refrain from assigning the play to any of the aforementioned playwrights, though John Marston, who became a member of the clergy in 1610, a few short years after the appearance of the play, would be a most intriguing candidate for authorship.

4 All references are to the Nottingham Drama text edition of the play, Simon Shepherd (ed.), The Family of Love (Nottingham, 1979). This edition uses act and scene designations as well as continuous line numbers.

5 'The Bishops report a certain heresy, called the Family of Love, with a monstrous speech, affirming all its sectaries will be saved, and all others rejected and damned. The heresies are founded on Dutch books by H.N. [Hendrik Niclas] otherwise nameless.' Earl of Crawford (ed.), Tudor and Stuart Proclamations, 1485-1714, Vol.1, England and Wales, (Oxford, 1910), 279. On Familism and language, see Julia G Ebel, 'The Family of Love: Sources of its History in England', Huntington Library Quarterly 30 (1966-67); Janet Halley, 'Heresy, Orthodoxy, and the Politics of Religious Discourse: The Case of the English Family of Love', Representations 15 (1986); Joanne Altieri, 'Pregnant Puns and Sectarian Rhetoric: Middleton's The Family of Love', Mosaic 22 (1989); Kristen Poole, Radical Religion from Shakespeare to Milton: Figures of Nonconformity in Early Modern England (Cambridge, 2000).

6 Jonathan Z. Smith, Map Is Not Territory: Studies in the History of Religion (Leiden, 1978); and To Take Place: Toward a Theory of Ritual (Chicago, 1987).

7 Smith has not explicitly theorized this 'third map', except for arguing that it seeks to overcome the spatial constraints of the other two maps (Map, 301).

8 Ibid, 301.

9 Henri Lefebvre, The Production of Space, trans. Donald Nicholson-Smith (Oxford: 1991), 188. 
10 Divided by Faith: Religious Conflict and the Practice of Toleration in Early Modern Europe (Cambridge, MA, 2007), 8.

11 Joseph Leo Koerner, The Reformation of the Image (Chicago, 2004), 404.

12 Evangelium Regni, in George Huntston Williams, The Radical Reformation, $3^{\text {rd }}$ edn (Kirksville MO, 2000), 725. Calvin, drawing on Pauline epistles to the Corinthians, writes: 'We are the temple of God, from the fact that 'the Spirit of God dwelleth in us" (1 Cor 3:15, 6:19; 2 Cor 6:16). Citing St Augustine, he observes, 'that we are not to make a temple to him, but to be ourselves that temple', in John T. McNeill (ed.) Institutes of the Christian Religion (Louisville KY, 1960), 1.13.15.

13 On 'house churches' in the Roman Empire, see Jeanne Halgren Kilde, Sacred Power, Sacred Space: An Introduction to Christian Architecture and Worship (Oxford, 2008), 16.

14 Building Codes: The Aesthetics of Calvinism in Early Modern Europe (Philadelphia PA, 1999), 30.

15 In his treatise on architecture (ca 1452-4), Leon Battista Alberti discusses the foundation of Rome through the drawing of the sulcus primigenius or 'initial furrow'; see Joseph Rykwert, Neil Leach, and Robert Tavernor, trans., On the Art of Building in Ten Books (Cambridge, 1988), 101. See also Gilles Deleuze and Félix Guattari on the emergence of sacred space within the Urstaat, the political carving of the city from an undifferentiated environment; Robert Hurley, Mark Seem, Helen Lane, trans., Anti-Oedipus: Capitalism and Schizophrenia (New York, 1977), 237. Henri Lefebvre observes that in the first cities sacred space emerged from the enclosure and separation of 'absolute space' (The Production of Space, 234). On the significance of sacred space to cities, see Emrys Jones, Metropolis (Oxford, 1990), 39-40.

16 On Perret and Andreae, see Per Gustaf Hamberg, Temples for Protestants (1955; rpt Göteborg SE, 2002). See also Tommaso Campanella vision of city enclosed by seven concentric walls, with a magnificent sun temple at the very centre, The City of the Sun (1602).

17 Hubertus Lutterbach, Der Weg ins Täuferreich von Münster: Ein Ringen um die heilige Stadt (Münster DE, 2006).

18 Hendrick Niclaes, Terra Pacis: A true testification of the spirituall Lande of Peace, which is the spirituall Lande of Promise, and the holy Citee of Peace or the heavenly Ieruslaem: and of the holy and spirituall People that dwel therein: as also of the Walking in the Spirit, which leadeth thereunto (Cologne DE, 1575), Early English Books Online (EEBO), 47.

19 J.W. Martin, Religious Radicals in Tudor England (London, 1989), 57.

20 Christopher Marsh, 'The Gravestone of Thomas Lawrence Revisited', in Margaret Spufford, The World of Rural Dissenters (Cambridge, 1995), 213. 
21 The Displaying of an Horrible Secte of Grosse and Wicked Heretiques, naming themselves the Familie of Love, with the lives of their Authours, and what doctrine they teach in corners (London, 1578), J5r.

22 Benjamin Kaplan, 'Fictions of Privacy: House Chapels and the Spatial Accommodation of Religious Dissent', American Historical Review (2002), 1036.

23 Ibid, 1036.

24 Margaret Aston, 'Segregation in Church', Studies in Church History 27 (1990).

25 Daphne Spain, Gendered Spaces (Chapel Hill NC, 1992), 19.

26 Henry Smith, A Preparative to Marriage (London, 1591), EEBO, 43.

27 Amanda Flather, Gender and Space in Early Modern England (London, 2007), 91-2.

28 On the body and sacred space, see Mary Douglas, Purity and Danger: An Analysis of Conceptions of Pollution and Taboo (London, 1966); Sarah Coakley (ed.), Religion and the Body, (Cambridge, 1997); Rudolf Bell, Holy Anorexia (Chicago IL, 1985); Caroline Walker Bynum, Holy Feast and Holy Fast: The Religious Significance of Food to Medieval Women (Berkeley CA, 1987).

29 Miri Rubin, Mother of God: A History of the Virgin Mary (New Haven CT, 2008).

30 'The Image of Both Churches', in Select Works of Bishop Bale (Cambridge, 1849), 633-4.

31 Mircea Eliade, The Sacred and the Profane: The Nature of Religion, trans. Willard Trask (New York, 1959).

32 Stephen DeStaebler, 'Reflections on Art and the Spirit: A Conversation', in Stephen DeStaebler and Diane Apostolos-Cappadona (eds), Art, Creativity, and the Sacred, (New York, 1984).

33 On space and the doctrine of the Incarnation, see Philip Sheldrake, Spaces for the Sacred: Place, Memory, and Identity (Baltimore MD, 2000).

34 Radical Religion, 101.

35 'Pregnant Puns', 54.

\section{Performance, Print, and the Senses: Aretino and the Spaces of the City}

To say that Pietro Aretino (1492-1556) was a man in touch with his senses would be a significant understatement. Aretino frequently evokes what we could describe as different sensory registers in his works. In the process, he opens the door for us into the debates and concerns surrounding the senses in the mid-sixteenth century and creates himself as a character who revels in, or who is assaulted by, the varieties of sensory experience. ${ }^{1}$ Sometimes he 